\title{
Peningkatan Kesehatan Mental Wirausahawan di Era Covid-19 dengan Penyuluhan Al-Qur'an
}

\author{
Improvement the Mental Health of Entrepreneur in the Covid-19 Era with Al-Qur'an \\ Counseling
}

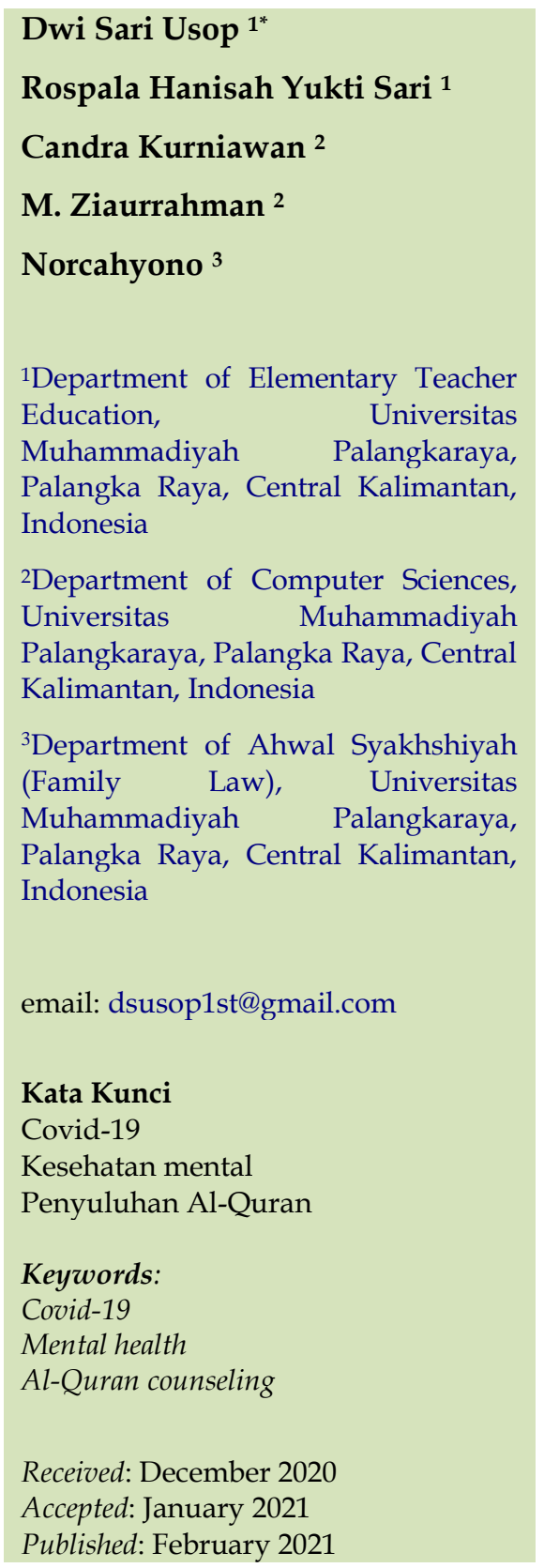

\begin{abstract}
Abstrak
Pandemi virus corona 2019 (Covid-19), memberikan dampak luas bagi perekonomian di Indonesia. Salah satunya bagi wirausahawan kecil. Peraturan pemerintah untuk menjaga jarak serta mengurangi keberadaan di tempat-tempat keramaian serta sifat dari penyebaran virus corona yang sangat cepat menyebabkan banyak toko atau usaha yang harus tutup atau sangat menurunnya jumlah pembeli atau bahkan tidak ada pembeli. Kondisi ini tentu memberikan efek psikologis negatif pada para wirausahawan kecil yang dapat menyebabkan menurunnya daya tahan tubuh. Salah satu upaya untuk mengatasinya ialah melalui pemberian penyuluhan Al Qur'an dan praktik pengamalannya dalam kehidupan sehari-hari yang mana diharapkan kekuatan jiwa wirausahawan semakin meningkat dan mampu menghadapi kehidupan di dalam suasana covid19 dan selanjutnya.
\end{abstract}

\begin{abstract}
The 2019 coronavirus pandemic (Covid-19) had a broad influence on the economy in Indonesia. One of them was a little entrepreneur. Government regulation to maintain distance and decrease public places and characters from the swift spread of coronavirus caused many stores or businesses to close or greatly decrease the number of buyers or even no buyers. This condition certainly negatively affected little entrepreneurs, which could cause a decrease in immunity. One of the efforts to overcome was through giving Al Qur'an counseling and activity practice in daily life where was expected more increase the strength of the entrepreneur's spirit and could face life in covid-19 and next.
\end{abstract}

(C) 2021 Dwi Sari Usop, Rospala Hanisah Yukti Sari, Candra Kurniawan, M Ziaurrahman, Norcahyono. Published by Institute for Research and Community Services Universitas Muhammadiyah Palangkaraya. This is Open Access article under the CC-BY-SA License (http://creativecommons.org/licenses/by-sa/4.0/). DOI: https://doi.org/10.33084/pengabdianmu.v6i2.1866 


\section{PENDAHULUAN}

Sejak terjadi pandemi covid-19, berbagai problematika multidimesi terjadi di beberapa negara, termasuk Indonesia. Adapun salah satu sektor yang terkena dampak dari pandemi covid-19 adalah sektor ekonomi. Sektor ekonomi merupakan sektor yang paling merasakan dampak akibat pandemi covid-19 ini. Permasalahan sistemik sektor ekonomi era covid-19 pun terjadi, hal ini berupa kemiskinan sistemik meliputi PHK massal, kelaparan, kehilangan tempat tinggal (Sumarni, 2020).

Pandemi Covid-19 telah menyebabkan sektor perekonomian global mengalami perlambatan dalam pertumbuhannya sehingga hal ini berdampak pada perekonomian nasional menjadi tidak stabil. Resesi ekonomi di Indonesia pun terjadi dalam beberapa bulan terakhir. Dampak yang paling dirasakan dalam resesi ekonomi adalah menurunnya daya beli masyarakat karena banyaknya terjadi PHK dan pendapatan pun menurun drastis alhasil dapat mengancam kelangsungan hidup masyarakat termasuk pedagang dan UMKM (Fahrika \& Roy, 2020).

Virus ini telah menyebabkan kelumpuhan pergerakan perdagangan nasional hingga perdagangan global. Laju pertumbuhan ekonomi pun mengalami penurunan tajam bahkan minus. Hampir setiap lapisan masyarakat mengalami dampak resesi ekonomi termasuk para pedagang. Menurunnya daya beli masyarakat akibat pendapatan yang menurun telah menyebabkan omset penjualan para pedagang atau pengusaha menurun drastis bahkan terancam gulung tikar. Hal ini tentu akan berimbas pada kesehatan mental para pedagang atau pengusaha yang khawatir terhadap keberlangsungan hajat hidup mereka (Kennedy et al., 2020). Gangguan kesehatan mental akan mempengaruhi kondisi kejiwaan seseorang dan secara otomatis juga berpengaruh terhadap kesehatan fisik seseorang. Gangguan kesehatan mental dapat berupa split personality yang menyebabkan seseorang sulit untuk menemukan ketenangan dan kebahagiaan hidup, kecemasankecemasan dan keteganganjiwa sehingga menyebabkan menurunnya produktifitas dalam menjalankan roda perekonomian mereka (Firdaus, 2016).

Solusi permasalahan yang ditawarkan yakni melalui pemberian Penyuluhan Al-Qur'an dan praktik pengamalannya dalam kehidupan sehari-hari. Kegiatan penyuluhan tidak saja berkaitan dengan pemberian pemahaman $\mathrm{Al}$ Qur'an untuk memberikan kesehatan jiwa. Tetapi juga ada pemberian materi-materi lainnya yang mendukung di dalam pelaksanaan usaha dan pemahaman mengenai situasi terkini. Materi-materi tersebut berkaitan dengan selfhealing atau penyembuhan diri, pembuatan catatan keuangan digital untuk mempermudah kegiatan usaha, dan teknik promosi melalui media sosial seperti facebook dan instagram (Maqbul et al., 2019).

Selain itu, pengamalan Al Qur'an untuk meningkatkan kesehatan mental juga diberikan melalui kegiatan bersedekah di panti asuhan. Melalui kegiatan ini diharapkan, peserta dapat saling berbagi dan kekuatan jiwa menghadapi masalah hidup berkaitan dengan covid-19 meningkat. Self healing sebagai keterampilan seseorang dalam mengelola diri baik secara fisik, mental emosi maupun secara spirit supaya hidup lebih selaras, lebih sehat, lebih waras, lebih bahagia (Rahmawati et al., 2020).

Dalam praktiknya, self-healing merupakan istilah yang salah satunya menggunakan proses yang berprinsip bahwa sebenarnya tubuh manusia merupakan sesuatu yang mampu memperbaiki dan menyembuhkan diri melalui cara-cara tertentu secara alamiah, seperti treatment terapi, yoga dan meditasi, latihan, terapi warna dan cahaya, penyehatan aura, penyeimbangan dengan tangan dan pendulum, aromaterapi, terapi sentuhan, 
pikiran positif, affirmasi dan hipnosis (Bahrien \& Ardianty, 2017). Qur'anic Healing sebagai salah satu terapi yang menggunakan Al Qur'an sebagai dasarnya, di mana dengan membaca dan mendengarkan lantunan ayat suci Al Qur'an dapat mempengaruhi keadaan pikiran seseorang sehingga membuat rasa tenang dan bahagia yang berdampak mengurangi atau menghilangkan stres maupun tekanan yang dialami (Istiqomah, 2017). Dalam Qur'anic Healing atau Pengobatan Islamic Self Healing mempunyai dasar pemikiran dari pengobatan islam yang diadalamnya terdapat aspek hikmah faidah-faidah adanya penyakit, doa, dzikir dan herbal (pengobatan dengan air zam-zam) yang bertujuan untuk mendatangkan keridhaan Allah, menguatkan hati dan badan (Cita et al., 2016).

\section{METODOLOGI}

Peserta dalam kegiatan pengabdian masyarakat ini adalah para pedagang kecil di kota Palangka Raya. Sebelum kegiatan dimulai tim melakukan penjaringan peserta media media WhatsApp. Setelah terkumpul jumlah peserta yang bersedia mengikuti kegiatan, kemudian ditentukan waktu Kegiatan. Beberapa kegiatan yang dilaksanakan dalam kegiatan Pengabdian Masyarakat ini, yakni:

1. Penyuluhan Al Qur'an dan materi yang berhubungan dengan usaha

2. Penyuluhan melalui "berbagi" ke panti asuhan

Adapun kegiatan penyuluhan dilakukan dengan sistem tatap muka seperti yang tertuang pada Tabel I:

Tabel I. Metode pelaksanaan

\begin{tabular}{clc}
\hline No & \multicolumn{1}{c}{ Jenis Kegiatan } & Metode Pelaksanaan \\
\hline 1 & Penyuluhan dengan tema- & Tatap muka \\
& tema : \\
& a. Selfhealing \\
& b. & Teknik penghitungan \\
& digital untuk UKM & \\
& c. & Penggunaan media \\
& sosial sebagai media \\
& promosi \\
& d. $\begin{array}{l}\text { Kesehatan mental dalam } \\
\text { perspektif Al Qur'an }\end{array}$ \\
\hline
\end{tabular}

\begin{tabular}{lll}
\hline 2 & $\begin{array}{l}\text { Pengamalan Al Qur'an } \\
\text { melalui Berbagi produk ke } \\
\text { panti asuhan }\end{array}$ & Tatap muka \\
\hline
\end{tabular}

Tabel II berikut menggambarkan mengenai rincian kegiatan pengabdian masyarakat.

\begin{tabular}{|c|c|c|}
\hline No. & Waktu & Kegiatan \\
\hline 1. & $\begin{array}{c}\text { 17 Juni }-31 \text { Juli } \\
2020\end{array}$ & $\begin{array}{ll}\text { Persiapan Materi } & \text { dan } \\
\text { Perlengkapan } & \end{array}$ \\
\hline 2. & $\begin{array}{c}1 \text { Juli }-7 \text { Agustus } \\
2020\end{array}$ & $\begin{array}{l}\text { Menghubungi dan } \\
\text { berkoordinasi dengan peserta }\end{array}$ \\
\hline 3. & $6-7$ Agustus 2020 & $\begin{array}{l}\text { Koordinasi dengan Peserta } \\
\text { Kegiatan Pengabdian }\end{array}$ \\
\hline 4. & 8 Agustus 2020 & $\begin{array}{l}\text { Pelaksanaan kegiatan } \\
\text { Penyuluhan Al Qur'an }\end{array}$ \\
\hline 5. & 9- 31 Agustus 2020 & Persiapan kegiatan kedua \\
\hline 6. & $\begin{array}{l}\text { 1- } 11 \text { September } \\
2020\end{array}$ & Berkoordinasi dengan peserta \\
\hline 7. & 12 September 2020 & Pelaksanaan kedua \\
\hline 8. & $\begin{array}{l}12 \text { September }-30 \\
\text { November } 2020\end{array}$ & $\begin{array}{l}\text { Pengumpulan Laporan, } \\
\text { Video Kegiatan, dan artikel di } \\
\text { media massa }\end{array}$ \\
\hline
\end{tabular}

\section{HASIL DAN PEMBAHASAN}

Kegiatan dilaksanakan sebanyak 2 (dua) kali, yakni pada hari Sabtu, tanggal 8 Agustus 2020 dan 12 September 2020. Kegiatan dilaksanakan secara tatap muka. Awalnya kegiatan pengabdian ini berjudul "Peningkatan Kesehatan Mental Wirausahawan di Era Covid-19 dengan Terapi Al Qur'an". Ada beberapa kegiatan yang dilaksanakan, yakni terapi Al Qur'an, penyuluhan agama, kegiatan promosi, dan pembelian produk peserta. Kegiatan terapi Al Qur'an dan penyuluhan agama direncanakan dilaksanakan secara daring, dimana penyuluhan keagamaan direncanakan diisi oleh narasumber dari luar. Bukan oleh tim pengabdian masyarakat. Berbagai persiapan disusun, seperti memohon kesediaan narasumber mengisi kegiatan, pembuatan brosur kegiatan, pencarian peserta, pengiriman undangan kegiatan via WhatsApp.

Seiring berjalannnya informasi, diketahui bahwa pengisian materi harus dilaksanakan oleh tim pengabdian masyarakat secara keseluruhan. Selain itu, para peserta yang mendaftar kegiatan sampai mendekati hari pelaksanaan sangat sedikit dan semua peserta juga 
hanya mendaftar kegiatan penyuluhan agama. Tidak ada yang mendaftar untuk mengikuti terapi.

Setelah proses diskusi bersama anggota tim, ada perubahan judul dan teknik pelaksanaan kegiatan. Judul kegiatan menjadi "Peningkatan Kesehatan Mental Wirausahawan di Era Covid-19 dengan Penyuluhan Al Qur'an". Kegiatan yang awalnya dilaksanakan secara daring diubah menjadi tatap muka dan sesuai protokol kesehatan covid-19. Proses pencarian peserta kegiatan dilaksanakan kembali via WhatsApp dan secara lisan. Hasilnya, ada 10 peserta yang mengikuti kegiatan. Kegiatan dilaksanakan hari sabtu, 8 November 2020 di ruang rapat lantai 2 Universitas Muhammadiyah Palangkaraya pukul 08.00 WIB. 10 orang peserta berasal dari latar belakang pekerjaan yang berbeda-beda, sebagaimana tercantum pada Tabel III:

Tabel III. Daftar pekerjaan peserta

\begin{tabular}{cll}
\hline No & \multicolumn{1}{c}{ Jenis Pekerjaan } & Jumlah \\
\hline 1 & Sewa rumah & 1 Orang \\
2 & Cleaning Service & 2 Orang \\
3 & Cleaning service dan membuka & 2 Orang \\
& usaha & \\
4 & Penjual makanan ringan & 3 Orang \\
5 & Penjahit dan berjualan sembako & 1 Orang \\
6 & Sembako & 1 Orang \\
\hline
\end{tabular}

Kegiatan penyuluhan Al Qur'an dilakukan secara protokol kesehatan. Peserta memakai masker dan duduk berjarak. Tim pengabdian masayarakat juga menyiapkan handsanitizer yang digunakan peserta etika baru masuk ruangan. Setelah peserta hadir semua, kegiatan diawali dengan pembukaan oleh pembawa acara dan tilawah Al Qur'an Surah Ar Rahman. Dilanjutkan dengan pemberian penyuluhan. Kegiatan penyuluhan terdiri dari empat tema yang diberikan oleh tim pengabdian masyarakat. Tema tersebut tertuang pada Tabel IV berikut:

Tabel IV. Tema-tema penyuluhan

\begin{tabular}{cl}
\hline No & \multicolumn{1}{c}{ Jenis Kegiatan } \\
\hline 1 & Selfhealing \\
2 & Teknik penghitungan digital untuk UKM \\
3 & Penggunaan media sosial sebagai media promosi \\
4 & Kesehatan mental dalam perspektif Al Qur'an \\
\hline
\end{tabular}

Kegiatan dilaksanakan dengan sistem panel, yakni seluruh tema disampaikan oleh tim pengabdian masyarakat sampai selesai, kemudian dilanjutkan dengan sesi tanya jawab. Memperhatikan tema-tema tersebut di atas, pemilihan tema diseuuaikan dengan kondisi dan kebutuhann masyarakat saat ini yang sedang berhadapan dengan pandemi covid-19. Bebagai kesulitan dirasakan, salah satunya kesulitan perekonomian. Kebutuihan fisik dan batin harus terpenuhifisik dan psikis. Pandemi coid-19 mengarahkan masyarakat kepada penggunaan teknologi komunikasi dan informasi lebih intens. Oleh sebab itu, berbagai ketrampilan fisik dan psikis harus dimiliki masyarakat. Ketrampilan psikis ialah mampu menjaga kesehatan dan menyembuhkan diri dengan kemampuan sendiri (self healing), serta memahami dan mengamalkan Al Qur'an. Antara self healing dan pengamalan $\mathrm{Al}$ Qur'an dapat berjalan beriringan sebab memiliki keterkaitan satu dengan lainnya (Mardhatillah, 2015).

Sementara itu, ketrampilan fisik yang harus dimiliki masyarakat saat ini ialah penguasaan teknologi komunikasi dan informasi. Berbagai sistem dikembangkan untuk mempernudah masyarakat melakukan berbagai hal seperti mengatur keuangan dan mempromosikan barang dagangan. Seluruh tema dianggap memiliki saling keterkaitan antara satu dengan lainnya. Apabila dijalankan dengan baik dan seimbang, maka insya Allah masyarakat akan sehat.

Kegiatan dilaksanakan dengan sistem panel, yakni seluruh tema disampaikan oleh tim pengabdian masyarakat sampai selesai, kemudian dilanjutkan dengan sesi tanya jawab. Pada awal tema 4, narasumber mengajak peserta untuk meregangkan tubuh dengan meminta peserta untuk memijat bahu peserta lain secara bergantian. Setelah dirasakan cukup, penyuluhan tema keempat dimulai hingga pukul 11.00 WIB. 
Kegiatan penyuluhan tahap kedua dilakukan pada hari Sabtu, 12 September 2020 bertempat di panti asuhan “"Berkah" yang beralamat di Jl. G. Obos km. 5,5 Palangka Raya. Kegiatan yang dilakukan ialah "berbagi" kepada anak-anak di panti asuhan tersebut. Melalui hasil diskusi dan seleksi, peserta yang mengikuti kegiatan tahap dua ini hanya berjumlah empat orang, yakni dua orang penjual makanan ringan dan dua orang penjual sembako. Enam peserta lainnya tidak diikutkan sebab dalam kegiatan ini, barang-barang yang diberikan ke anak-anak panti asuhan ialah barang dagangan peserta sendiri. Sedangkan 1 orang peserta memiliki usaha sewa rumah, 1 orang peserta lainnya diketahui baru melahirkan sehingga tidak memungkinkan mengikuti kegiatan, dan 4 orang peserta lainnya memiliki pekerjaan lain selain berwirausaha, yakni cleaning service.

Tim dan peserta diterima baik oleh pengelola panti asuhan dan didoakan. Semoga apa yang menjadi hajat dari peserta dan tim pengabdian masyarakat dapat terlaksana dan berjalan dengan sukses sesuai jalur yang diridhai Allah swt. Melalui kegiatan ini, tim pengabdian masyarakat berharap, peserta dapat terus termotivasi untuk berpikir positif dan berbuat kebaikan sesuai jalan yang benar sehingga menjadi pribadi yang sehat fisik maupun mentalnya. Hasil capaian berupa bertambahnya wawasan peserta mengenai konsep self healing, teknik penghitungan digital untuk UKM, penggunaan media sosial sebagai media promosi, dan kesehatan mental dalam perspektif Al Qur'an. Di awal kegiatan hari Sabtu, 8 Agustus 2020, tim pengabdian masyarakat memberikan pre test berupa kuosioner yang berisikan pertanyaan-pertanyaan sebagai berikut:

1. apa motivasi anda mengikuti kegiatan ini?

2. apa yang anda rasakan selama masa pandemic covid-19 ini?

3. efek apa yang anada rasakan pada usaha anda?

4. upaya apa saja yang dilakukan untuk mempertahankan usaha Anda?

5. jenis usaha yang anda geluti saat ini?

6. proses pemasaran usaha?

Diakhir kegiatan, peserta juga diberikan post test berupa kuisioner dengan pertanyaan-pertanyaan sebagai berikut:

1. hal apa saja yang anda dapatkan selama mengikuti kegiatan ini?

2. materi apa saja yang anda dapatkan pada pemateri 1pemateri 5 ?

3. apa rencana anda ke depan terhadap usaha anda setelah mengikuti kegiatan ini?

4. bagaimana kesan dan pesan anda terhadap pemateri?

5. bagaimana kesan dan pesan anda terhadap kegiatan ini?

Hasil post test menunjukkan jawaban yang positif, dimana peserta memperoleh informasi tentang cara menghadapi masa pandemi covid-19 dengan baik, menjadi terdorong motivasinya untuk tetap semangat, pantang menyerah, berpikir positif, menjaga kesehatan, bersyukur, bersaing secara positif, ingin mencoba usaha lain sesuai kondisi saat ini, ingin melakukan promosi di media sosial, kembali pada pedoman hidup yaitu $\mathrm{Al}$ Qur'an. Selain itu, peserta juga memberi usulan agar ke depan bisa dibentuk UMKM berkelompok, kegiatan dapat dilaksanakan lebih luas lagi kepada para pengusaha-pengusaha kecil, serta kegiatan penyuluhan dapat dibuat secara lesehan agar peserta lebih santai dan tidak tegang.

\section{KESIMPULAN}

Pemberian informasi dan pelatihan, seperti penyuluhan Al Qur'an sangat diperlukan oleh masyarakat sebagai penyejuk jiwa di era covid-19 ini. Khususnya bagi para wirausahawan. 


\section{UCAPAN TERIMA KASIH}

Teriring doa agar Allah swt melimpahkan kita semua memberikan kesehatan dan kebahagiaan. Penulis mengucapkan terima kasih kepada semua pihak yang telah berpartisipasi dalam terealisasinya kegiatan pengabdian masyarakat dan artikel ini.

\section{REFERENSI}

Bahrien, B., Ardianty, S. 2017. Pengaruh Efektivitas Terapi Self Healing Menggunakan Energi Reiki terhadap Kecemasan Menghadapi Ujian Skripsi. Psympathic: Jurnal Ilmiah Psikologi. 4(1):141-148. https://doi.org/10.15575/psy.v4i1.1227

Cita, E.E., Wulandari, T., Istanti, Y.P. 2016. Terapi Islamic Self Healing Terhadap Quality of life pada Klien Gagal Ginjal Kronis dengan Terapi Hemodialisa. IJNP (Indonesian Journal of Nursing Practices). 3(1):43-57. https://doi.org/10.18196/ijnp.v3i1.2220

Fahrika, A.I., Roy, J. 2020. Dampak pandemi covid 19 terhadap perkembangan makro ekonomi di indonesia dan respon kebijakan yang ditempuh. Inovasi: Jurnal Ekonomi, Keuangan dan Manajemen. 16(2):206-213. http://dx.doi.org/10.29264/jinv.v16i2.8255

Firdaus, F. 2016. Spiritualitas Ibadah Sebagai Jalan Menuju Kesehatan Mental Yang Hakiki. AlAdyan: Jurnal Studi Lintas Agama. 11(1):117-137. https://doi.org/10.24042/ajsla.v11i1.1440

Istiqomah, M. 2017. Terapi Qur'ani Bagi Penyembuhan Gangguan Kejiwaan (Analisis Pemikiran Muhammad Utsman Najati tentang Spiritualitas al-Qur'an bagi Penyembuhan Gangguan Kejiwaan). Konseling Religi: Jurnal Bimbingan Konseling Islam. 8(1):133-150. http://dx.doi.org/10.21043/kr.v8i1.2489

Kennedy, P.S.J., Harya, T.W.P., Tampubolon, E., Fakhriansyah, M. 2020. Analisis Strategi Lockdown Atau Pembatasan Sosial Dalam Menghambat Penyebaran Covid-19: Sebuah Tinjauan Teoritis. Image: Jurnal Riset Manajemen. $\quad$ 9(1):48-64. https://doi.org/10.17509/image.v9i1.24189
Maqbul, M., Mahmud, M.N., Amin, M., Muhammad, F. 2019. Proses Pelaksanaan Strategi Penyuluhan Agama Islam Di Kabupaten Barru. Jurnal Diskursus Islam. 7(3):425-452. https://doi.org/10.24252/jdi.v7i3.11972

Mardhatillah, M. 2015. Ayat-Ayat al-Qur'an dalam Suf Healing Method; Pengobatan Alternatif Penderita AIDS ala Muhammad Zuhri. Jurnal Studi Ilmu-ilmu al-Qur'an dan Hadis. 16(1):107121. https://doi.org/10.14421/qh.2015.160106

Rahmawati, A.P., Setiawan, C., Naan, N. 2020. Nilai Sufistik Dalam Prosedur Self Healing. Syifa alQulub: Jurnal Studi Psikoterapi Sufistik. 5(1):1728. https://doi.org/10.15575/saq.v5i1.9153

Sumarni, Y. 2020. Pandemi Covid-19: Tantangan Ekonomi dan Bisnis. Al-Intaj: Jurnal Ekonomi dan Perbankan Syariah. 6(2):46-58. http://dx.doi.org/10.29300/aij.v6i2.3358 